\title{
"The Politics of Foreign Aid" \\ U.S. Assistance for Reform in Ukraine and Poland
}

TANYA NAROZHNA

\section{N T R O D UC T I O N}

"Foreign aid is first and foremost a technique of statecraft. It is, in other words, a means by which one nation tries to get other nations to act in desired ways" (Baldwin 3). This statement was made almost four decades ago. Yet when one looks at the U.S. support for the post-Soviet countries in transition, one realizes that Western assistance has been and continues to be driven by inherently political considerations. Indeed, following the Soviet demise, traditional Cold War rationales for assistance strategies disappeared, prompting reconsiderations of donors' priorities. The prospects of the former socialist states' transition to liberal democracy and a market economy opened up new opportunities for donor governments and agencies. Many of them redirected resources from the Third World and became actively involved in the formulation, financing and implementation of multiple aid programs in Eastern Europe and the former Soviet Union. By the mid-1990s they had disbursed nearly $\$ 40$ billion in aid funds to the region. The transition has increasingly become a strategy implemented by Western donors, illuminating the fundamental and ongoing tension between the economic and political self-interests of donors and the developmental needs of recipients.

More importantly, beginning in the early days of the transition, the U.S., and the West more generally, did not view the entire post-socialist world as monolithic. Western donors tended to discriminate in favor of the countries of Eastern and Central Europe and treat them more as potential partners, while the Soviet nations, except for the Baltic states and Russia, were denied recognition of the right to statehood. In this paper I will analyze U.S. support, or lack thereof, for transition reforms in two neighboring countries. I will demonstrate that in contrast to Poland, stumbling U.S.-Ukraine relations made the challenge of maintaining independence a far greater task than was expected. This explains much of the frustration with transition reforms and much of the blame discourse over Western unwillingness to embrace Ukraine. However, I will also argue that the donor's self-interested policy toward Ukraine is not a single reason for developmental under-achievement in this country. Many of today's prob- 
lems reach back to the lack of commitment on behalf of Ukraine's political elites to pursue developmental objectives in their country, as well as to the idealist views of former Ukrainian dissidents about the West and their euphoric expectations of how foreign aid could help their country. Whatever the illusionary and potential benefits of foreign assistance, the experiences of Poland, to whom the West was favorably disposed throughout the 1990s, and Ukraine, who went largely unnoticed by donors, demonstrate that development should begin at home.

\section{COMMON INHERITANCE, DIFFERENT WELCOME}

Although both post-socialist East European countries and former Soviet countries started from a common inheritance, socialism was practiced in these countries with varying degrees of orthodoxy (Serafin 2). Indeed, prior to 1989 the legitimacy of the socialist regime in Poland was continually challenged by the efforts of reform-oriented communists to liberalize the one-party system; by the independent position of the Catholic Church, which served as a venue for civic activity; and by the oppositional activity of Solidarity, an organization with 10 million members, which fulfilled the function of political party and civil society structure simultaneously (Buchowski 79-98). In Ukraine, on the other hand, the independent movements of cultural dissent that took shape in the $1950 \mathrm{OS}$ and 1960 o flourished in a highly restricted environment. They underwent several successive "thaws" and "freezes," retreating underground and returning as the regime's pressures eased. The decisive factor that brought about Ukraine's independence was not democratic protest but the Soviet collapse. In contrast to Poland, the weakness of democratic opposition forces was evident not only in their late appearance but also in their inability to consolidate. Having failed to represent a politically viable force, these scattered groups of democrats and nationalists were not strong enough to define the ends and means of the subsequent post-socialist transformation. In fact, after the seventeen year long rule of Volodymyr Shcherbytsky, Ukraine was at the dawn of independence one of the most conservative and repressive republics of the Soviet Union, lagging far behind the pace of liberalization in the Baltic states and Russia (Prizel 11-29). No surprise, then, that unlike Poland, whose independence was wholeheartedly supported by the West, Ukraine's cause attracted little attention outside the Ukrainian diaspora. Moreover, Ukraine's entitlement to statehood was openly unwelcome. Preoccupied with concerns related to the end of the Cold War, the 'West' feared that the Soviet collapse would lead to the proliferation of nuclear states. Ukraine would then become the third-largest nuclear power in the world. In his famous speech in August 1991, which William Safire of The New York Times called "the Chicken Kyiv speech," President George Bush urged the 
Ukrainian parliament to remain part of the Soviet Union and not push for "suicidal nationalism." Similarly, Margaret Thatcher pointed out that Great Britain did not establish diplomatic relations with provinces, drawing an analogy between Ukraine and Quebec. Politically, the U.S., and the West more generally, were slow in coming to view Ukraine as a country on its own terms rather than a regional outpost. In 1993, the U.S. policy toward the "post-Soviet space" was outlined in the 22-page paper that Larry Eagleburger left to Secretary of State Warren Christopher: "If reform succeeds in Russia, it may not assure the success of reform in the other states of the FSU; but if reform fails in Russia, it most assuredly will mean the failure of reform throughout the former Soviet empire" (Talbott 45). No surprise then that, even after independence, it was through the prism of their relationship with Russia that Western capitals and institutions defined their policies toward Ukraine.

While reformists in Ukraine were still struggling for the recognition of their country's legitimacy, in the late 1980 os Poland was already leaning on the supportive shoulders of Western donors. The country rejoined the World Bank in 1986 and in 1990 received its first loan. In 1989 the European Union established its largest aid program to the region - PHARE, which was focused on Poland and Hungary. The PHARE program was to assist the countries of Central Europe in their preparations for joining the European Union. In late 1989, the U.S. Congress adopted the SEED (Support for East European Democracy) legislative package, which authorized nearly $\$ 1$ billion for democratic and market reform in Poland and Hungary. In 1992, Poland and Hungary were the largest recipients of U.S. aid to the region.

Kyiv, unfortunately, soon forgot the sobering speeches of the leaders of the free world and remained greatly misled by illusions that Ukraine's European orientation, its record on ethnic tolerance and firm commitment to renounce its nuclear arsenal, declared in 1991, would lead to closer relations between Ukraine and the West. As a matter of fact, the West's deep concern with the destiny of the "orphan missiles" (78) left on Ukraine's territory after the Soviet collapse (over 2,0oo warheads located on 176 intercontinental ballistic missiles) resulted in the country being rediscovered by international actors, but only for a while. Following its commitment to renounce its nuclear arsenal, Ukraine voiced requests for compensation, economic assistance and security assurances in return for the removal of strategic nukes. The U.S. and Russia, with Ukraine's participation, "quickly reached broad agreement on a complex deal that would result in Russia getting the warheads along with American money to help with their dismantlement and Ukraine getting various forms of assistance from the U.S. as well as debt relief from Russia and international assurances on its sovereignty" (109). When Ukrainian President Leonid Kravchuk tried to reopen this issue during Bill Clinton's two-hour "visit" to Ukraine in January 1994, Presi- 
dent Clinton and Secretary of State Christopher "told Kravchuk in the bluntest of terms that if he backed out of the deal that had already been made it would be a major setback for Ukraine's relations with both Russia and the U.S." (112). After signing the Trilateral Agreement with the U.S. and Russia in early 1994 in Moscow, which required Ukraine to dismantle its entire nuclear arsenal by June 1996, Ukraine's relations with the U.S. improved somewhat. However, even though Ukraine became the third largest recipient of American assistance after Israel and Egypt, it received far less than it requested (a two-year \$9oo million U.S. aid package, of which $\$ 350$ million was to expedite disarmament and another $\$ 50$ million was from Japan for the same purpose). Ambassador Morningstar, the U.S. assistance coordinator to the former Soviet Union, reported to Congress that in 1996 Ukraine received the third lowest per capita assistance among the 12 new independent states (NIS) of the former Soviet Union. Of the funds allocated for the nations of the NIS, the rate of expenditure for Ukraine was also the third lowest (Iwanciw 7). Much of the delay in assistance Clinton's administration justified by the slow pace of economic reform in Ukraine. This justification, however, left no explanation for the higher rate of expenditure for countries such as Turkmenistan, Tajikistan and other NIS nations that were behind Ukraine in economic reform. Having achieved its major goal with regard to Ukraine, i.e. denuclearization, the West moved on to other preoccupations, whereas Ukraine's membership in NATO and the EU turned into a "strategic aim" for an indeterminate future. Additionally, stumbling relations with the U.S. resulted in much frustration over the unwillingness of the free world to embrace Ukraine and in further distancing from the West.

\section{CONTINUITY IN THE U.S. POLICY TOWARD UKRAINE}

If a single word could be said to describe the U.S. policy toward Ukraine under the presidencies of Bush, Clinton, and Bush Jr., this word would be continuity. U.S.-Ukrainian relations over the last couple of years have been exceedingly strained as Kuchma's presidency has grown ever more authoritarian and has been marked by corruption scandals and alleged arms sales to Baghdad in violation of the international arms embargo imposed on Iraq by the United Nations. According to The New York Times, in the last five years Ukraine has become the sixth-largest arms suppliers in the world (Wines). The question of sales to Iraq and respect for U.N. sanctions has been an ongoing issue in the discussions between top American and Ukrainian officials for some time. However, no measures have been streamlined against Ukraine or its president until recently. Relying on an analysis of clandestine recordings made in July 2000 by a presidential bodyguard, Mykola Melnychenko, the U.S. government made a decision, perhaps more important in view of the approaching war against Iraq, to sus- 
pend \$55 million or about 35 percent of the Freedom Support Act assistance to Ukraine, which finances democratic and economic reforms. Assistance to dismantle the Soviet-era nuclear technology remained intact (U.S. Department of State). The move to suspend aid to Ukraine was made on the basis of "some indications," but in the absence of definitive proof that the counter-stealth radar Kolchuga was actually sold and delivered to Iraq (Baker A18). This decision came in a larger package, part of a wide-scale review of U.S. policy towards Ukraine and President Kuchma in particular, which is likely to isolate Ukraine from the West even further (Warner and Wolffe).

\section{THE POLITICS OF COMPLAINTS AND MULTIPLE VECTORS}

It has become common to blame big powers for mistreating smaller countries - it is much harder to acknowledge one's own inability, lack of political will and experience to make one's case and stand up for it. It is true that in contrast to Poland, Ukraine's appearance on the international scene was unwelcome. Its cultural, psychological, ideological and historical divisions, as well as the failure of reforms at home further reinforced the pessimistic prognosis of numerous analysts about the prospects of its viability as a state. However, the underlying causes of Ukraine's transitional under-achievements should be looked for within the country. When Ukraine's independence emerged as an unanticipated by-product of the collapsed center, loyal members of the former Communist elite were quick to realize that a new state opened up multiple opportunities, ranging from ministerial portfolios and parliamentary seats to a privileged monopolistic position under new quasi-market rules. These new-old elites, represented by a trinity of government, Parliament, and the so-called "red" directors (the directors of huge Soviet enterprises, who made fortunes on early privatization), were most interested in delaying economic reforms because it was in a non-transparent, unreformed, or rather semi-reformed, economy that these regenerated, capitalist-oriented Communist elites could best pursue their individual and group interests, living off corruption and rent-seeking, and advancing oligarchic capitalism. ${ }^{1}$ On an international level, they were equally uninterested in establishing Ukraine's presence: the less attention Ukraine received from the international community, the more room was left for the rentier-oligarchic elites shadow political and economic maneuvering. It became an axiom in international politics that the countries "lacking well-entrenched political institutions have come to rely more heavily on foreign policy as a tool of nationbuilding and as a means to sustain a national identity" (Prizel). However, selfinterested Ukrainian leaders failed to follow this rule - their economic interests kept them focused on Russia. Consequently, the greatest achievement that Ukrainian diplomacy could boast by late 2001 was, in the words of Ukraine's 
most prominent former foreign minister, Borys Tarasiuk, preservation of independence. ${ }^{2}$ While Poland's foreign policy during the early days of transition was marked by enormous activism directed toward a "return to Europe," Ukrainian leaders were busy balancing their individual and other countries' interests and complaining about the West's underestimation of Ukraine's geopolitical and strategic importance. Once the third-largest nuclear power in the world, with the third-largest army in Europe after Russia and Germany, but ever since independence heavily dependent on Russia for cheap energy, Ukraine has had to keep a shaky balance between Russia and the West for a decade, sticking to a "multi-vector policy" - a euphemism designed to disguise the absence of a clear-cut foreign policy strategy. Only recently, in May 2002, after Russia gave the green light for a rapprochement between Kyiv and the Alliance, did Ukraine drop its unpromising neutrality status and announced its desire to join NATO. These developments signified a possible breakthrough in Ukraine's relations with NATO, which was seriously hampered by Kuchma's uninvited appearance at recent NATO summit in Prague. Similarly, EU-Ukrainian relations can boast hardly any progress. In fact, they have never developed beyond positive intentions and mutual declarations of good will. Although Ukraine adopted an official seven-year plan for integration into the EU, and the Union, on its part, developed a strategy regarding Ukraine for 2002-2006, the country is still perceived by EU officials as, in the words of the advisor to the president on international relations, Anatoliy Orel, part of the "amorphous post-Soviet space."

Meanwhile Poland successfully set the tone in its negotiations with Russia on NATO enlargement at a time when even the U.S. was in retreat on the issue. In August 1993, Poland's President Lech Walesa and Russian President Boris Yeltsin signed "a joint declaration affirming that Poland had a sovereign right to provide for its own security and that if Poland chose to join NATO, it would not conflict with Russia's interests" (Talbott 95-6). Yeltsin's announcement at a press conference in Warsaw left many of the American and Russian officials speechless. After the deal with Russia was made, opening the doors of Western institutions was only a matter of time. From the onset it was clear that Poland was not only internationally visible, but that the country was viewed by the West as being part of it, which led to its being rapidly integrated into Western structures. In 1994 Poland joined NATO's Partnership for Peace Program and five years later, in 1999, became a NATO member; in 1998 the European Union opened talks on Poland's membership, and the December 2001 EU summit included Poland on the list of countries expected to join the Union in January 2004. 
CONCLUSION: DEVELOPMENT SHOULD BEGIN AT HOME In a speech before the Bretton Woods committee, Czech Prime Minister Vaclav Klaus said:

After three years of a relatively successful fundamental systemic transformation of the Czech economy and society, my experience tells me that the role of external factors in this process is relatively small and that reform begins and ends at home. Transforming a post-communist country into a functioning market economy and into a free society requires, first, a clear vision of the goal the reformers follow, second, a clear and pragmatic strategy on how to achieve it and, third, the ability of politicians to mobilize sufficient political support for the implementation of the transformation program. These domestic preconditions are crucial for the success of the changes and cannot be supplemented by any form of foreign aid or assistance. ${ }^{4}$

Even though Polish leaders tended to overly rely on Western assistance in the early days of transition, they had a commitment, vision, and strategy for the development of Poland. The Ukrainian political establishment lacked all of these features. In the mid-199os, when Ukraine was still complaining about untimely and/or insufficient aid, disillusionment, frustration, and resentment with Western assistance grew among aid recipients in Eastern Europe. Western assistance to the post-socialist world has become entrapped in the discourse of blame, with recipients blaming donors for the gulf between actual aid and the rhetoric of aid on the one hand and donors blaming recipients for misuse of assistance money and insufficient reform efforts on the other. Poland was among the first recipients to become disillusioned with aid. In 1992, Walesa voiced this growing resentment with aid at the European Parliamentary Forum in Strasbourg, charging the West with making "a tidy profit off of the Polish revolution. [...] The West was supposed to help us in arranging the economy along new principles, but in fact it largely confined its efforts to draining our domestic markets" (Harden A1).

Development aid has often been used by donors as a convenient shield to promote their self-interests rather than to respond to the developmental needs of recipients. The transfer of wealth from the developed to the developing world has usually been justified on the grounds that the lack of capital was the major impediment to economic development. However, as Peter Bauer has observed, "Lack of money is not the cause of poverty, it is poverty"; therefore to have money is the "result of economic achievement, not its precondition" (6). Poland subsequently requested more capital support and less technical assistance. It was the time when the words of Vaclav Klaus proved right - reform should begin and end at home.

\section{REFERENCES}

Baker, Peter. "Ukraine Denies Selling to Iraq." Washington Post (September 25, 2002): A18. Baldwin, David. Economic Development and American Foreign Policy, 1943-1962. Chicago:

University of Chicago Press, 1966. 
Bauer, Peter T. "Creating the Third World: Foreign Aid and Its Offspring." Journal of Economic Growth 2.4 (1987): 6.

Buchowski, Michal. "The Shifting Meanings of Civil and Civic Society in Poland." Civil Society: Challenging Western Models. Eds. Chris Hann and Elizabeth Dunn. London, New York: Routledge, 1996. 79-98.

Harden, Blaine. "Poles Sour on Capitalism." Washington Post (February 5, 1992): A1.

Havrylyshyn, Oleh. "The Political Economy of Delayed Reform in Ukraine." Ukraine: The Search for a National Identity. Eds Sharon Wolchik and Volodymyr Zviglyanich. Lanham, MD: Rowman and Littlefield Publishers, Inc., 200o. 49-68.

Iwanciw, Eugene M. "Letter to the Editor." The Ukrainian Weekly (October 27, 1996): 7.

Klaus, Vaclav. “Speech for Bretton Woods Committee." Washington, D.C., October 15, 1993. retrieved from http://www.czech.cz/washington/press/k93-bret.htm

Prizel, Ilya. "Nation-Building and Foreign Policy." Ukraine: The Search for a National Identity. Eds. Sharon L. Wolchik and Volodymyr Zviglyanich. Lanham, MD: Rowman and Littlefield Publishers, Inc., 200o. 11-30.

Serafin, Joan. "Introduction." East-Central Europe in the 199os. Ed. Joan Serafin. Boulder, San Francisco, Oxford: Westview Press, 1994.

"Shliakh Ukrainy do Obyednanoi Evropy Bude Duzhe Dovhym," Interview with Taras Vozniak, lead-editor of Ji-magazine, Postup 40.879 (21-27 March, 2002).

Talbott, Strobe. The Russia Hand: A Memoir of Presidential Diplomacy. New York: Random House, 2002.

U.S. Department of State, Daily Press Briefing, Richard Boucher, Spokesman. September 24, 2002.

Warner Tom and Richard Wolffe, "U.S. Launches Review on Ukraine Policy." Financial Times (September 24, 2002) retrieved from http://news.ft.com/servlet/ContentServer? pagename=FT.com $/$ StoryFTFullStory \&c $=$ StoryFT \&cid $=1031119629212 \& \mathrm{p}=1012571727162$

Wines, Michael. "U.S. Suspects Ukraine of Selling Radar to Iraq." The New York Times (September 24, 2002) retrieved from http://www.nytimes.com/2002/09/24/international/ europe/24UKRA.html

\section{ENDNOTES}

${ }^{1}$ Cf. Havrylyshyn.

${ }^{2}$ Borys Tarasiuk gave a talk at the University of Alberta (Edmonton, Canada) at the invitation of the Canadian Institute of Ukrainian Studies in November 2001.

3 "Shliakh Ukrainy do Obyednanoi Evropy Bude Duzhe Dovhym," Interview with Taras Vozniak, lead-editor of Ji-magazine, Postup 40 (879), 21-27 March, 2002.

${ }^{4}$ Vaclav Klaus, "Foreign Aid for a Postcommunist Country - Experience and Prospects." Speech for Bretton Woods Committee, Washington, D.C., October 15, 1993.

Tanya Narozhna is a PhD candidate in political science at the University of Alberta (Canada). She has worked as an editorial assistant for Global Governance Journal and as a research assistant at the Canadian Institute of Ukrainian Studies. Her present research focuses on the role of foreign assistance in the post-socialist transition. 